\title{
Providing Effective Feedback to EFL Student Teachers
}

\author{
Holi Ibrahim Holi Ali ${ }^{1,2} \&$ Hamed Ahmed Al-Adawi ${ }^{1,2}$ \\ ${ }^{1}$ School of Education \& Professional Development, University of Huddersfield, UK \\ ${ }^{2}$ Department of English Language \& Literature (DELL), Rustaq College of Applied Sciences, Oman \\ Correspondence: Holi Ibrahim Holi Ali, Rustaq College of Applied Sciences, Rustaq, PO Box: 10, PC 329, \\ Oman. Tel: 968-2687-5244. E-mail: howlli2@yahoo.com
}

Received: March 22, 2013 Accepted: April 17, 2013 Online Published: May 20, 2013

doi:10.5539/hes.v3n3p21 URL: http://dx.doi.org/10.5539/hes.v3n3p21

\begin{abstract}
Feedback on school practicum is of utmost importance for student teachers to help them to develop their pedagogical and teaching skills. This paper attempts to collect data from both student teachers and their mentors in an ELT teacher training programme in Oman to answer the questions which are raised by this study: 1) What kind of feedback do student teachers receive in their practicum? 2) What are the student teachers' and mentors' views of feedback on the practicum? 3) What type of practicum feedback is more effective, oral or written? This study also aims to offer practical ideas that would empower both student teachers and supervisors in improving the practice of giving and receiving feedback in practicum. The data was analyzed quantitatively and qualitatively. The statistical approach that is adopted in the questionnaire depends on frequency and percentage. The item of high frequency and percentage reflects the most significant, required answers for the three study questions. The findings indicated that student teachers and their mentors perceived their feedback practices on practicum positively; however the student teachers believed that both types of feedback are important to them but they are in favour of written feedback more than oral one. The study offered some pedagogical implications and recommendations with regard to feedback on practicum.
\end{abstract}

Keywords: effective feedback, EFL student teachers, practicum, mentors, oral \& written feedback

\section{Introduction}

School-based practicum feedback is considered a highly important, influential and central component in helping student teachers learn to teach and teacher education programmes (Soares \& Soares, 2002 \& Simpson, 2006 cited in Al Sohbani, 2012). Practicum is viewed as critical to the development of student teachers because it is their first hands-on experience with teaching (Al Sohbani, 2012, p. 196). Effective practicum feedback offers student teachers an opportunity to get both oral and written feedback from their mentors. Moreover, practicum feedback should allow dialogue between students and their mentors and promote their thinking and reflection skills and consolidate their pedagogical skills. Effective practicum feedback should focus on the task and the associated learning outcomes and inform the student teachers whether they are on the right track. This study is an attempt to share with practitioners some insightful ideas and information that would inform their giving of feedback to their student teachers during their school-based practicum. It strives to answer questions raised by the study: What kind of feedback do student teachers receive in their practicum? What are the student teachers' and mentors' perceptions of feedback on the practicum? What type of practicum feedback is more effective, oral or written? To answer these questions data was collected through focus group interview with 12 mentors and a questionnaire was distributed to both student teachers of English language speciality and their supervisors. The findings are believed to be of a great value to both teachers and training programmes across the region to run effective school-based practicum.

\subsection{Statement of the Problem}

Ministry of Higher Education (MoHE) in Oman strives to provide quality education to all students across the country. One of the important programmes which have received its supreme attention is the EFL teacher training programmes. This study was promoted by the need of society for effective and well-trained EFL teachers in both primary and secondary schools in Oman. EFL teacher training programmes are crucial for developing student teachers' pedagogical skills (Al Sohbani, 2012). However, these programmes are currently limited to two institutions across the country. They are run only by Sultan Qaboos University at the faculty of education and 
Rustaq College of Applied Sciences at the English language and literature department. Research shows that there are five main factors underlying effective practicum supervision. The five factors are: personal attributes, system requirements, pedagogical knowledge, modelling, and feedback. Each factor has its significance in helping student teachers to improve their pedagogical skills (Hudson et al., 2008 cited in Al Sohbani, 2012, p. 163). Thus, this study is centred on one of the most important factors which is feedback. Student teachers often depend on their mentors' feedback in helping them to improve their pedagogical and personal skills. However, there is sometimes dissatisfaction from student teachers with feedback they receive and the way it is given. Therefore, providing effective feedback can only be achieved through investigating both trainees and mentors' views. Thus, this study is conducted to investigate student teachers' and their mentors' perceptions about the practicum feedback, their level of satisfaction with practicum feedback, because student teachers' commitments and involvement in the practicum is linked to their level of satisfaction and motivation (Broabent, 1998, cited in Ferrier-Kerr, 2009), the kind of feedback they receive, and the problems they encounter with their practicum feedback and how these problems could be alleviated. The current study attempts to seek answers to the three questions raised by the study.

\subsection{Significance of the Study}

This study was set out in the Sultanate of Oman, specifically Rustaq College of Applied Sciences, Sultanate of Oman. The College runs a teacher training programme in English language and literature. One of the major and essential components of the programme is school-based practicum. Therefore, the current study is considered to be the first one of its type to be conducted on school based practicum of Rustaq College of Applied Sciences. The findings are expected to provide valuable data for both ELT practitioners and decision makers which could make changes in improving the way feedback is given to trainee students. It also deals with the most fundamental issue in teaching, which is student teachers' and supervisors' views about feedback given, reflections and problems they usually face in their school-based practicum feedback.

The significance of the present study is due to the fact that it drives its magnitude from the fact that the results would help student teachers and supervisors to improve their school-based practicum in general. Moreover, there was a lack of information about students' views about the feedback they get and problems they faced during practicum in this particular context. Therefore, this study strives to explore both student teachers' and supervisors' views about practicum feedback and the challenges they face and to find ways to further improve it. It is hoped that the findings will be of a great value to teachers at Rustaq College and teacher training programmes across the country, and to other ESL/EFL teachers in other contexts to run an effective school-based practicum.

\subsection{Objectives of the Study}

The main objectives of the study are: to explore the kind of feedback student teachers receive in their practicum, to investigate student teachers' and their mentors' perceptions and beliefs about feedback they receive on practicum, and to identify the type of feedback which is more effective to them during their school-based practicum.

\subsection{Research Questions}

1) What kind of feedback do student teachers receive in their practicum?

2) What are the student teachers' and mentors' views of feedback on the practicum?

3) What type of practicum feedback is more effective, oral or written?

\subsection{Context of the Study}

There are six colleges of applied sciences which operate across the Sultanate of Oman. These colleges were used to be colleges of education to produce teachers of various subjects. In 2007-2008 colleges of education were converted into colleges of applied sciences and they are affiliated to the ministry of Higher Education. These colleges are situated in different regions. Rustaq in south Batinah, Nizwa in Dakhilayah, Salalah in Dhofar, Ibri in Dhahirah, Sohar in north Batinah, and Sur in Shariqyia. These colleges of applied sciences offer diploma and bachelor degrees in fields such as business, finance and accounting, information technology (IT), engineering, media and communication, and English language \& literature, which is restrictively in Rustaq College of Applied Sciences.

Rustaq College of Applied Sciences offers a four-year EFL teacher training which leads to a B. Ed degree in English language and literature. This programme is unique because it is currently run in only two institutions which are Sultan Qaboos University and Rustaq College of Applied Sciences and both are affiliated to the 
Ministry of High Education in Oman. This programme is run for four years, and the main aim is to prepare qualified English language teachers for both primary and secondary schools. It is considered one of the fewest programmes across the country. School-based practicum is considered one of the significant and practical parts of the degree along with microteaching which is done at the college. School-based practicum is a five-credit hour course which students register in their final year. It is done in two semesters, fall and spring semesters in the final year. This course is meant to be a golden opportunity for student teachers to put what they have studied in theory into practice.

\subsection{How the School-Based Practicum Is Run in Rustaq College of Applied Sciences}

Rustaq College of Applied Sciences Teacher Training Programme follows the rationalist model which was founded by Schön (1983). This model is used in many EFL teacher training programmes around the globe such as in China, Oman, etc. This model views teacher education as learn-the-theory-and-then-apply it in practical contexts (Ur, 1992 cited in Yan \& He, 2010, 60). Student teachers are placed in schools at the beginning of the fourth year in both fall / spring semesters. Two mentors or supervisors are assigned to each school, and they need to work interchangeably and to swap each other for 7-8 weeks during the semester. Mentors are coming from multi-nationalities such as England, US, Oman, Sudan, Iraq, Tunisia, etc. The main role of the mentors is to observe the student teachers, evaluate and assess their pedagogical skills and provide them with effective feedback that is necessary for their professional and personal development. However, "the main objective of the cooperating teachers is not only to evaluate the performance of the student teachers, but rather to provide them with essential feedback in order to facilitate their professional development and practices in order to develop their teaching strategies and motivate them to work better" (Glickman et al., 2004 cited in Al Mekhlafi, 2012,161). A ready-made classroom observation form is provided by the ministry which contains five main categories: personality, language proficiency, lesson preparation, instruction, and classroom management and achievement of aims along with 20 statements. A scale ranging from 5 as the highest to 1 as the lowest is used to award marks. Also the trainees are assessed by the senior teachers and the administrators of the respected schools. The mentors usually have the lion's share in assessing and evaluating their student teachers pedagogical skills and in giving the marks which is $(80 \%)$ and $(20 \%)$ for the senior teacher and the school administration. The student teachers are usually placed in public schools which are convenient to them in terms of their accommodations. The vast majority of teachers in these schools are Omanis, and they are expected to provide the necessary support for the trainee teachers.

\section{Methodology}

This study is an exploratory descriptive study which aims to explore mentees' and mentors' perceptions about their practicum feedback and some of challenges they encountered with practicum feedback and to provide ways for improving feedback practices. A questionnaire and focus group interview were used to collect data from both students and their mentors to answer the study questions at the end of the practicum. Questionnaires were designed by the researchers and it was validated by experts in term of focus, content and wordings. All wordings and clarity were checked and verified against the study questions and objectives to iron out their wrinkles and to meet the intended results. Consequently, a new version was drafted and distributed. According to Selinker and Shohamy (1989, p. 185), reliability is information on whether the instrument is collecting data in a consistent and accurate way. Therefore Spearman-Brown's equation $(r=2 r / 1+r)$ was used to calculate and compute the reliability coefficient of the questionnaire. It was found approximately 0.6110 which is positive reliability.

The students' questionnaire contains three parts. Part one which follows Likert-3 points scale starts from agree to disagree and it centers on student teachers' perceptions about their practicum and its feedback. Part One focuses on students' perceptions of their practicum feedback and the way they receive it from their mentors. Part Two revolves around student teachers' satisfaction with their school-based practicum feedback. Part Three includes open-ended questions which collect student teachers' responses about feedback effectiveness. This part aims to generate qualitative data for the study to answer the first and third research questions. Additionally, mentors' questionnaire consists of three parts. Part one includes mentors' perceptions about the practicum and its feedback. Part Two includes mentors' views about the practicum and the feedback they give. Finally, Part Three contains open-ended questions which were intended to generate data that could answer the other research questions. In addition, two focus group interviews were conducted in the college with 10 supervisors out of 12 and field notes were also taken to reinforce the data collected via a questionnaire. Quota sampling procedures was used to identify the sample because the number of the female students is bigger than the number of male students.

\subsection{The Demographic of the Participants}

The participants of the study comprised (46) student teachers out of 150 and (12) out of 20 mentors. All the 
student teachers are Omani and they have been studying in the EFL teacher training programme for four years, and they are expected to be prospective English language teachers in both primary and secondary schools in Oman. The age group of the student teacher ranges between 22-24 years and their mother tongue is Arabic. Whereas, the supervisors are Omanis, British, Americans, Sudanese, Iraqis, Tunisians, etc. All of the mentors are experienced teachers and they have been working in Oman for several years.

\section{Review of Related Literature}

\subsection{Impact of School-Based Practicum on Teacher Education}

Practicum is important for providing quality teachers which are important for every community to develop. Brog (2009) believes that high quality teachers will create a high quality education system. Thus, practicum is of utmost importance for the trainee teachers to put their theoretical knowledge into practice and reflect on their practices. Smith \& LevAri cited in Smith (2010) assert that there is agreement in the literature that the practicum is a major component in the education of teachers. Graham 2006 in Smith (2010) adds it is "an important rite of passage in a teacher's career". Further, Mtika claims that "teaching practicum is integral part to trainee teachers' professional development, and shapes their beliefs and thinking about teaching" (2011, p. 552). Moreover, teaching practicum is considered one of the most influential aspects of pre-service teacher education (Guyton, 1989; Haigh, 2001, cited in Ferrier-Kerr, 2009, p. 790). Hussein (2011) advocates that "quality education is impossible without competent, committed and ethically well-founded teacher work force was underscored" (2011, p. 335). A practicum is viewed as a setting designed for the task of learning a practice. In a context which approximates a practice world, students learn by doing although their doing usually falls short of real world work (Schon cited in Wilson \& I'Anson, 2006, p. 354). The terms 'field experience' in the US and 'professional learning experience' and 'teaching practice are used interchangeably to refer to the practicum (Zeegers and Smith, 2005 cited in Moody, 2009, p. 156). Stanton \& Giles (1989, 180 cited in Yan \& He (2010) defined the practicum as "field experiences that focus on professional practice and activities that are explicitly focused on pre-professional practice". Mentoring is associated with practicum which is a "helping' activity and it is meant to foster learning and develop them professionally based on an established mutual relationship, governed by trust and openness (Orland Barak and Yinon 2005; Timperley 2001 cited in Tellima et al. 2011, p. 139). Practicum is a central component of teacher education (Moody, 2009, 155). (Huling 1997, cited in Yan \& He 2010, p. 58) claims that the teaching practicum is an opportunity for student teachers to observe and work with real students, teachers and curriculum settings. They add to say that the support from the practicum or host school and the role of cooperating teacher are perceived by most of the respondents as crucially important. The main purpose of the practicum is to enable the pre-service teacher to put into practice the theoretical components of their course and engage in experiential learning and school-based research (VIT 2007, 13 cited in Moody, 2009, p. 157). The school-based practicum creates space for reflection which is not so possible in other situations and it provides opportunities for student teachers to become aware of their own pre-conceived notions of teaching and it plays a major role in forming the future generation of teachers (Smith, 2010 \& Wilson \& I'Anson, 2006).Additionally, teaching practicum is considered as one of the most critical components of teacher preparation with the greatest impact on teacher quality (Zeichner, 2010, Graham, 2006, Tang, 2003 cited in Mtika, 2011, p. 552). Thus, "well designed practicum is needed to ensure that teacher training institutions produce high quality teachers" (Zeichner 2010, Sobar, 2004, cited in Mtika, 2011, p. 552). During the practicum the trainee teachers are at the entrance gate of the teaching career and for them the dialogue with the mentors is crucial to their professional development. The mentees learn the very complex task of teaching which shapes their entire future career (Smith, 2010). Therefore, the quality of the practicum and feedback given is essential (ibid, p. 40).

\subsection{Importance of Practicum Feedback for Student Teachers}

Research on feedback reveals that quality feedback, whether spoken or written, helps learners to confirm the intended learning outcome of the learning and motivate them to move on and enables them to assess their own learning and performance and lets them to identify their next step (Black \& William, 1998, cited in White, 2007, 301). Feedback is currently seen as the heart of assessment for learning and teaching (Smith, 2010). Mentor feedback on practicum is viewed as the one which a trainer critiques a student teacher's lesson with positive and negative evaluation, and provides advice and suggestions for future use (Copland, 2011, p. 3832). Moreover, feedback enables student teachers to know their strengths and weaknesses by engaging in a dialogue with their mentors or supervisors and it should be dialogic between mentors and student teachers rather than didactic or imposed one (Timperley, 2007, cited in Smith, 2010, p. 38). Feedback and teaching practice are considered to be a central component in pre-service teacher training (Copland, 2009, p. 466). Concrete feedback would help the student teachers to "visualize their evolving style, clarify what they need to work on, and concretize their own 
vision of good teaching" (Feiman-Nemser, 2001, p. 23 cited in Moody, 2009, p. 163). White (2007) claims that constructive practicum feedback could highlight for student teachers the things that are important to focus on and directs their learning towards further critical learning. The practicum supervisor has many roles to play with their mentees. His/her role is not only an assessor but he has other different roles to play during his presence in the school with his mentees. He may play the following roles: a friend who is kind to his mentees and establishes good professional relationships with his mentees, which are crucial for successful practicum (Ferrier-Kerr, 2009). Additionally, he/she has to set a good model in terms of his teaching and other professional aspects. He/she is an assessor and supporter, which means that he/she should always be willing to help and available to his trainees. $\mathrm{He} / \mathrm{she}$ should also be an intermediary, who always helps his mentees to establish good work relationship with other people such as host school administrations and staff members. Further, a supervisor should also be a standard-prodder who supports his/her trainees to meet the standard, and door-opener by helping his student teachers to be in touch with people who are helpful and important in the profession. Ferrier-Kerr, (2009) claims that there is a consensus the trainers' roles should be as coaches, mentors, facilitators and supervisors (Ferrier-Kerr, 2009, p. 791). In addition, the role of the mentor or supervisor is seen as a highly complex and demanding one, because it is encompassing advisor, encourager, giver of feedback, observer, role model and supporter (Haigh \& Ward 2004, cited in Moody, 2009). According to Copland (2011) practicum feedback conference is usually done in five stages or tasks. Firstly, self-evaluation where trainee teacher discusses his / her own lesson and highlights the strong and weak points in his lesson and this is usually done in a short period of time. Secondly, mentor critiques the mentee's lesson with positive and negative evaluation and provides advice and suggestions. The trainee has to take feedback on board 'gracefully' because effective feedback should allow a dialogue between student teacher and supervisor and promote thinking and reflection and evokes and explores understanding (Black et al. 2002 cited in White, 2007, p. 300). Third, peer feedback in which trainees provide feedback to their peers on the strengths and weakness of their colleague's lesson which usually tend to be in a descriptive manner. Fourth, mentor asks trainees a series of questions about particular sections of their lessons. Finally, the clarification stage in which the trainees talk about things directly relevant to the lesson taught, and in this phase the trainees initiate the conversation (Copland, 2011, p. 3835). Research shows that there are four key elements for a positive practicum: support from the supervising teacher, freedom to develop own teaching style, constructive feedback, and approach to assessment (Moody, 2009, p. 159). Practicum feedback sessions should be in a dialogic process in which 'both mentor and student teacher must examine their aims, their concerns, and their expectations' (Fairbanks et al. 2000, 106 cited in Moody, 2009, p. 164). Supervisors are important for successful practicum and this is supported by the literature with a strong correlation between student teachers' dissatisfaction with their practicum and the negative perceptions of the supervising teacher (Morgan, 2007 cited in Moody, 2009, p. 160). Graham (1996 cited in White, 2007) suggests that student teachers can better evaluate their teaching performance and become more reflective of the feedback given when their supervisors and mentors ask questions like the following before giving any other feedback: Did you meet your objectives and goals? How do you know? If you were to teach this lesson again, what would you change? What did you learn about yourself and your students? Were your instructions clear? What did you see that made you feel good about the lesson? What went well for you and why? Do you think the children were on task? Why or why not? What did you want the children to learn? How did you know if they did? What can you see needs changing and how might you make these changes? (Graham, 1996, p. 38 cited in White, 2007, p. $301 \&$ White, 2009, pp. 124-125). Moreover, White (2009, p. 129) claims that spending a long time with student teachers after an observation lesson and giving both good quality written and oral feedback are important, but, the constrains of time under which most supervisors work are not supportive to this issue.

\subsection{Studies on Student Teachers' and Mentors' Perceptions about Practicum}

Studies related to student teachers' and their mentors' perceptions about practicum are reviewed to contextualize and set the ground for the study. A study conducted by Al Sohbani (2012) to explore EFL student teachers' views towards the practicum at Ajman University in the UAE, used a questionnaire to collect data from the respondents. The findings show that student teachers hold positive views about their cooperating teachers, the academic advisors, and their host school as well. However, the study used only questionnaires to collect data and feedback and other aspects of the practicum were beyond the scope of the study. Thus, this study focuses on student teachers' perceptions about the feedback they receive and other important aspects of the successful practicum feedback and both questionnaire and focus interviews were used to collect data which were overlooked by the previous studies.

Another study was carried out by Al Mekhalfi (2012) which aimed to explore EFL practicum cooperating teachers' attitudes, self-perceptions and practices in improving student teachers' grammar teaching strategies 
during their practicum at Sohar University in the Sultanate of Oman. The data were collected via literature-based instrument. The results confirm that mentors' self-perceptions on grammar teaching were positive and study recommends for further training for the cooperating teachers. Although this study was centered on mentors only rather than student teachers and it focuses on teaching grammar, it is still relevant to this study because it deals with similar context which is Oman. The methodology was overlooked because no questionnaires or interviews were used to collect data but only literature-based instrument was used. Thus, this study might yield better findings because both questionnaire and interview were used and they might yield solid findings and results.

Moreover, a study was conducted by Moody (2009) to investigate key elements in a positive practicum from the perspective of post-primary pre-service teachers in Victoria Australia. Four key issues are: the emotional and professional support given by the supervising teacher, the freedom for pre-service teachers to develop their own teaching style, the provision of specific and constructive feedback, and the approach to assessment. The results reveal that pre-service teachers considered their practicum was successful and they were generally satisfied with their feedback sessions and most of them were happy with the feedback they received. Moreover, a study conducted by White (2007) investigated a small group of student teachers about their pre-service teaching practice in New Zealand. The student teachers were asked about what they understood by the term feedback, how they expected feedback to be given what they hoped to gain from the feedback they received, and what they found useful in relation to their professional career and teaching practice. A questionnaire was used to collect data from the respondents. The findings show that spoken feedback was the most given and useful mode of feedback and they believed both written and spoken feedback met their expectations and they were perceived to be useful to them. However, written feedback was also widely received and also seen as useful by the majority of the students (White, 2007, p. 309). Therefore, (Babkie 1998 cited in White, 2007) maintains that both spoken and written feedback need to be given during the practicum and should cover positive and negative aspects. Further, the findings indicate that a mixture of both written and spoken feedback is likely to be the most effective for Year 1 student teachers in relation to their practicum (White, 2007, 310). Therefore, this study attempts to fill the gaps which were overlooked by the previous studies.

\section{Data Analysis and Discussion}

\subsection{Question 1: What Kind of Feedback Does Student Teachers Receive in Their Practicum?}

The qualitative data indicates that student teachers are getting two types of feedback, but they believe that written feedback is more effective. A student teacher said:

Both types of feedback are given. We need oral feedback to give the trainee teacher a chance to reflect on their lessons and give their reasons why did they do this rather than that. We need written feedback to remember what mistakes we did so this will help us to avoid them in the future.

Another student teacher reported:

Our mentors give both oral and written feedback. I believe that both of them should be given to help the students to reflect on their teaching practice.

\section{Student teachers noted:}

Both types of feedback are given. We need oral feedback to give the trainee teacher a chance to reflect on their lessons and give their reasons why did this rather than that. We need written feedback to remember what mistakes we made so this will help us to avoid them in the future. 
4.2 What Are the Student Teachers' and Mentors' Views of Feedback on the Practicum?

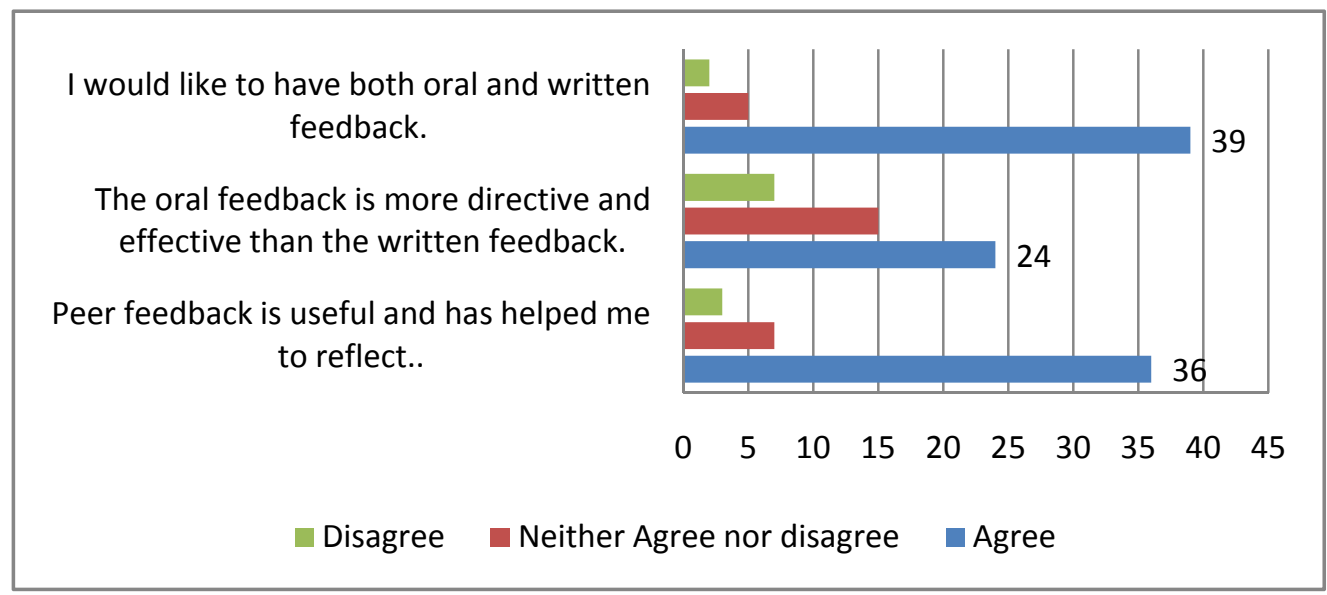

Figure 1. The student teachers' perceptions of feedback on practicum

The graph below illustrates student teachers' perceptions about practicum feedback. As for question 1, whether they would like both types of feedback or only one is enough, $(85 \%)$ agreed that both oral and written feedback are important to them. This finding corroborates with White's (2007) findings which show the fact that a mixture of both written and spoken feedback is likely to be the most effective student teachers in their practicum. This is supported by (Babkie 1998 cited in White, 2007) both spoken and written feedback need to be given during the practicum and should cover positive and negative aspects. In response to question 2 , whether oral feedback is more directive and effective than written feedback or not, (54\%) of the respondents agreed with the statement, $(32 \%)$ neither agreed nor disagreed, and (15\%) disagreed. Concerning question 3, whether peer feedback is helpful to them or not, $(78 \%)$ believed that peer feedback is useful and has helped them to reflect on their teaching practices, and (15\%) responded by 'neither agree nor disagree', and (7\%) disagreed.

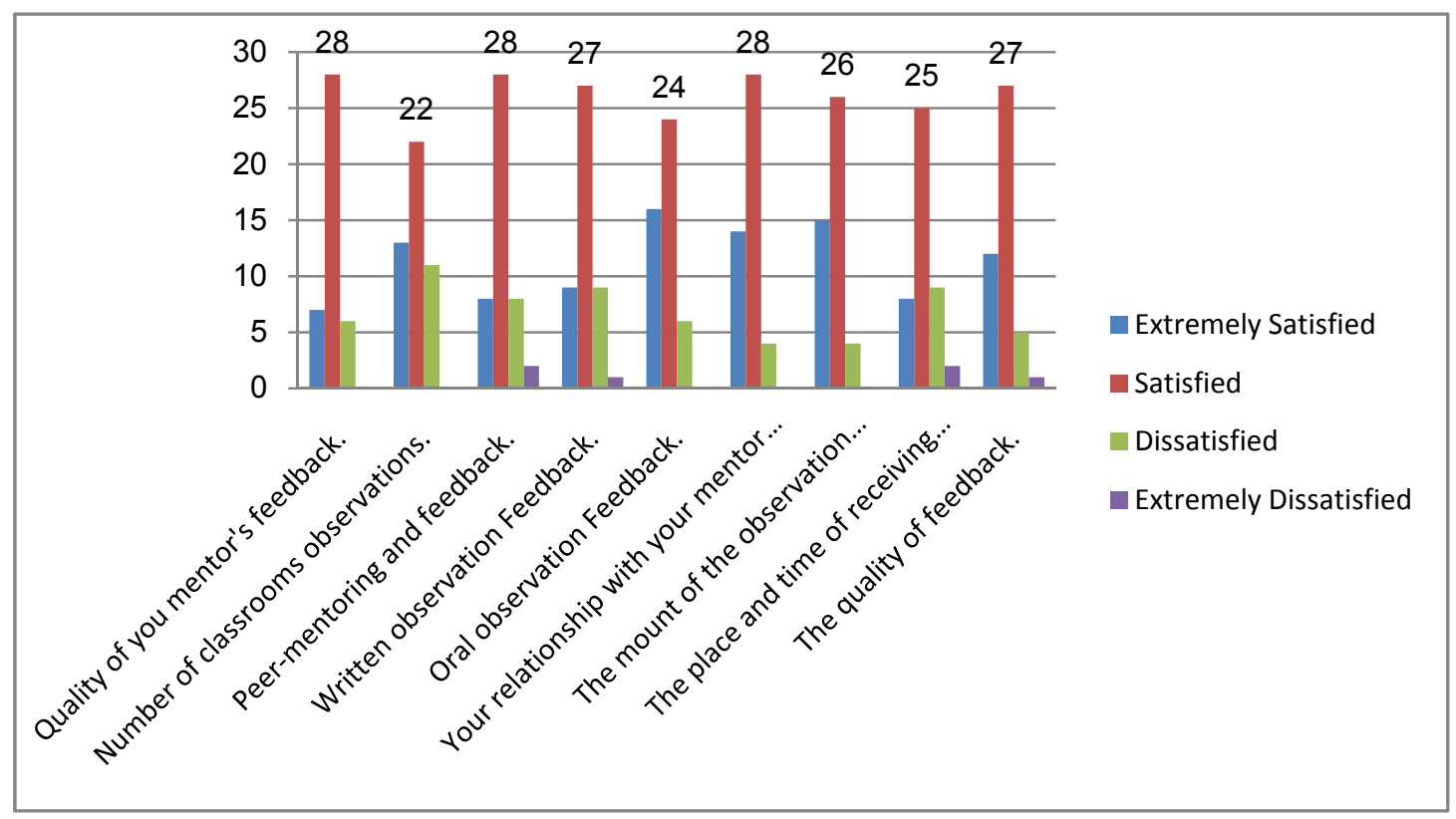

Figure 2. The student teachers' satisfaction with the feedback on school-based practicum feedback

This graph depicts the student teachers level of satisfaction with their practicum feedback. Regarding question 1, whether they are satisfied with quality of the feedback or not, $(15 \%)$ were extremely satisfied, $(61 \%)$ were satisfied, (13\%) were dissatisfied, and no one reported with extremely dissatisfied. Concerning the number of 
classroom observations, (28\%) were extremely satisfied with the number of observations, $(47 \%)$ were satisfied, (24\%) were dissatisfied, and no one was extremely dissatisfied. In response to respondents' perceptions about peer-mentoring and feedback, (17\%) were extremely satisfied, (61\%) were satisfied, and (17\%) were dissatisfied and only $(4 \%)$ were extremely dissatisfied. It is quite clear that the majority of the respondents were satisfied with the practicum peer-mentoring and feedback. As for question 5, whether they are satisfied with their written observation feedback or not, (19\%) of the respondents reported that they were extremely satisfied, and (59\%) were satisfied, (20\%) were dissatisfied, and only (2\%) were extremely dissatisfied. Regarding question 6, (30\%) of the respondents were extremely satisfied with their relationship with mentor and his/her feedback approach, (61) were satisfied, (9\%) were dissatisfied and no one was extremely dissatisfied. For question 7, (33\%) were extremely satisfied with the mount of their observation feedback, (57\%) were satisfied, (9\%) were dissatisfied, and no one reported by extremely dissatisfied. In response to question 8 , whether they are satisfied with place and time of feedback, $(17 \%)$ reported that they were extremely satisfied, $(54 \%)$ were satisfied, and $(4 \%)$ were extremely dissatisfied. Finally, as for question 9 which deals with respondents' satisfaction with the quality of the feedback, $(26 \%)$ of them were extremely satisfied, $(59 \%)$ were satisfied, $(11 \%)$ were dissatisfied, and only (2\%) were extremely dissatisfied.

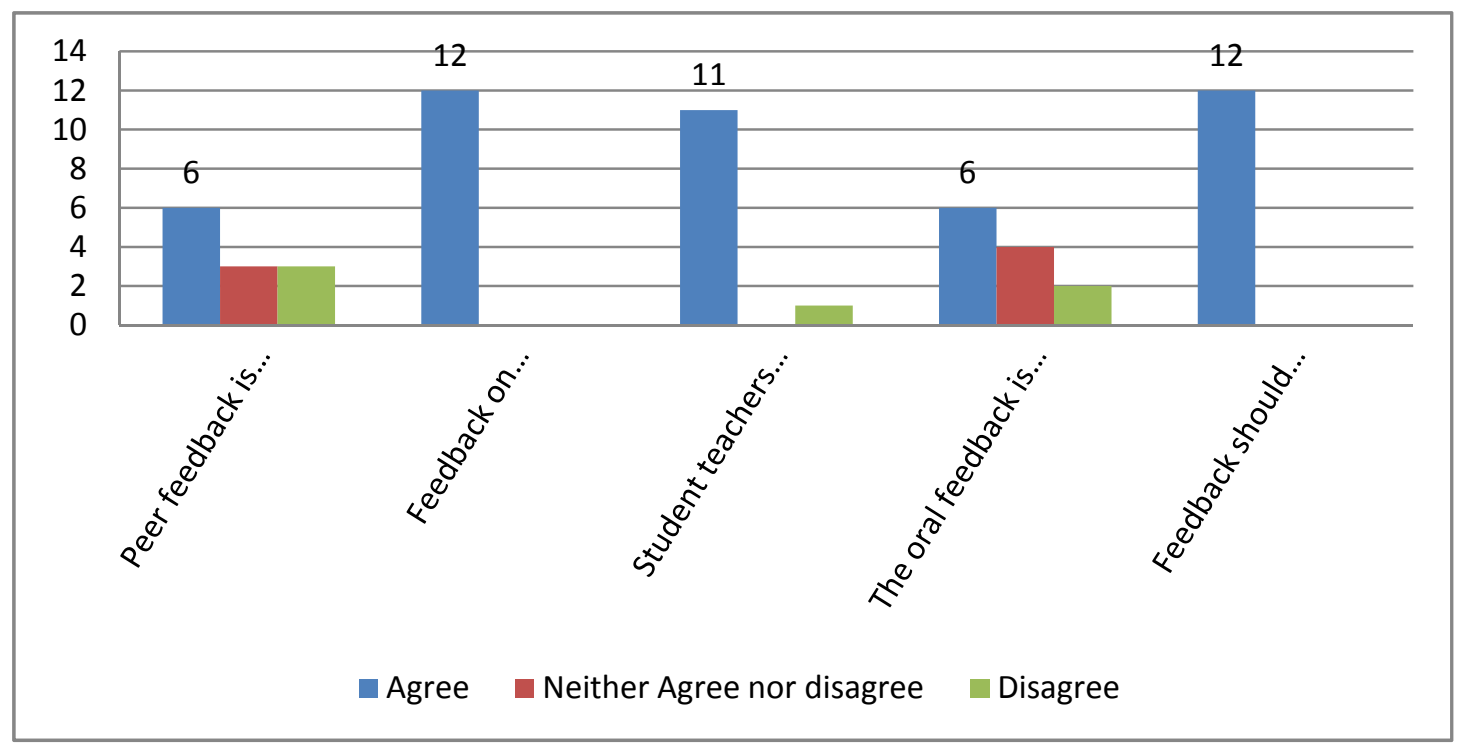

Figure 3. The supervisors' perceptions of feedback on practicum

This graph displays mentors' views about the practicum and its feedback. As for question 1, whether peer feedback is used in their practicum or not, $(5 \%)$ agreed with the statement, $(25 \%)$ neither agreed nor disagreed, and $(25 \%)$ disagreed with the statement. Regarding question 2, $(83 \%)$ agreed that practicum observations has helped them to know their students' instructional needs, $(8 \%)$ neither agreed nor disagreed, and no one disagreed. Concerning question 3, all the respondents (100\%) agreed that practicum feedback should include comments on lesson planning, teaching strategies, classroom management, personal attributes and language proficiency. As for question 4, whether student teachers are provided with both oral and written feedback, (92\%) of the mentors agreed that they give both oral and written feedback, no one neither agreed nor disagree and (8\%) disagreed with the statement. As for question 5, $(50 \%)$ of the respondents agreed that the oral feedback is more and effective for their students than written feedback, (33\%) neither agreed nor disagreed with the statement, and (17\%) disagreed. Regarding question 7, (100\%) of the respondents agreed that feedback should include positive and negative comments on their students' performance and no reported by other options. This is supported by Babkie (1998 cited in White, 2007) who maintains that practicum feedback should cover positive and negative comments. 


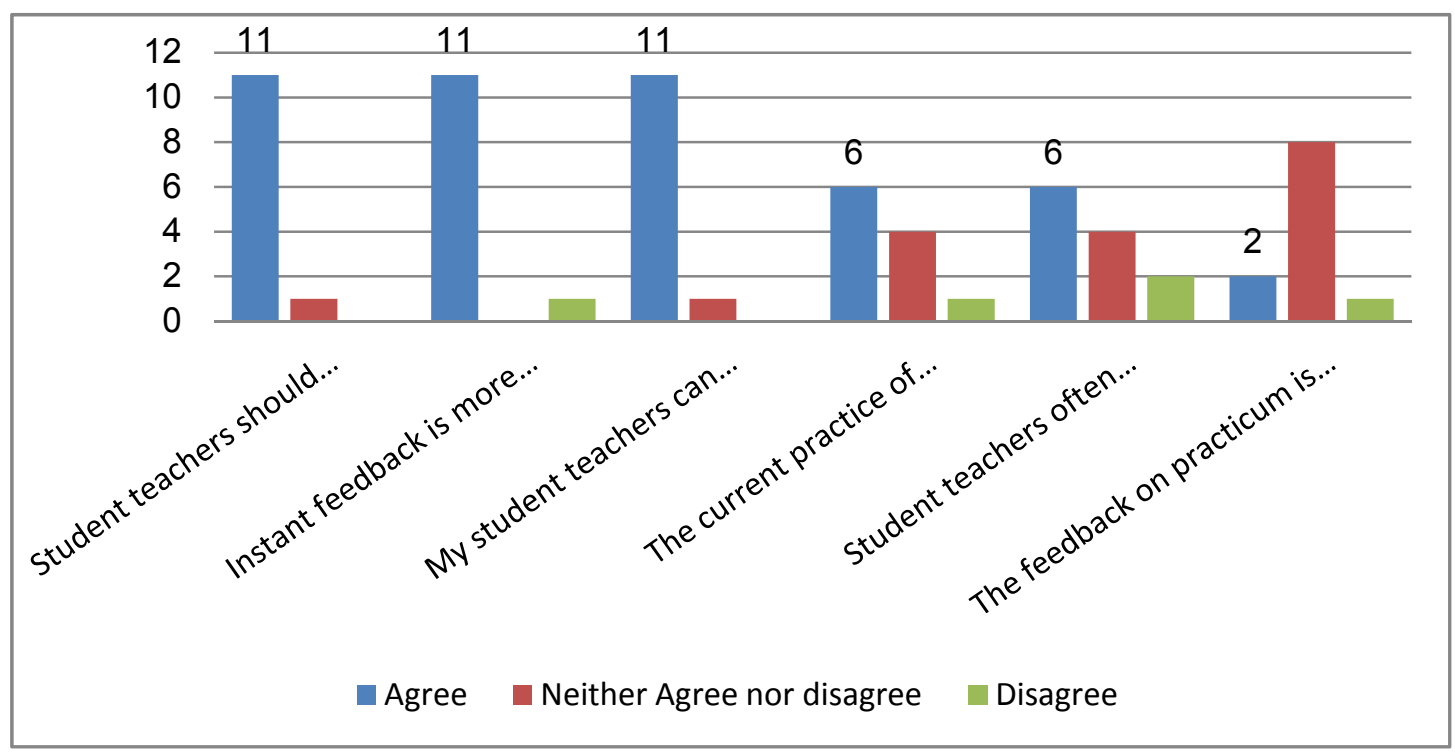

Figure 4. The supervisors' perceptions of feedback on practicum

This graph shows the mentors' perceptions about the practicum and the feedback they give. As for question 6, $(92 \%)$ of the respondents believed that student teachers should receive detailed comments on their performance, $(8 \%)$ neither agreed nor disagreed, and no one responded by disagree. Regarding question $7,(92 \%)$ agreed that instant feedback is more effective and helpful for students than delayed feedback, and (8\%) disagreed with the statement. Concerning question $8,(92 \%)$ agreed that their student teachers can easily understand their feedback on their performance, $(8 \%)$ neither agreed nor disagreed, and no one disagreed. In response to question 9 , whether their student teachers use their feedback and reflect on it regularly, $(75 \%)$ of the respondents agreed, and $(8 \%)$ neither agreed nor disagreed, and (8\%) disagreed with the statement. As for question 10 , whether the current practice of providing feedback on practicum needs to be improved or not, (5\%) agreed, $(33 \%)$ neither agreed nor disagreed with the statement, and only (8\%) disagreed. Concerning question 13, (50\%) of the mentors agreed that their student teachers often reflect on their feedback they receive on their performance, $(33 \%)$ neither agreed nor disagreed, and only (17\%) disagreed with the statement. Finally, whether the practicum feedback is consistent with what is taught on college-based practicum $1 \& 2$ or not, only (17\%) agreed with the statement, $(67 \%)$ neither agreed nor disagreed, and only $(8 \%)$ disagreed with the statement. It is quite obvious the majority of the mentors were not aware whether there is a consistency between college-based practicum theories and school-based practicum.

\subsection{Question 3: What Type of Practicum Feedback Is More Effective, Oral or Written?}

Question 3 is to be answered by the qualitative data that generated, through focus group interviews and open-ended questions of the questionnaires. In response to this question, the majority of the student teachers believed that written feedback is much more effective because they can refer to it in the future and they can reflect on it. This can be supported by quotations from their responses.

\section{Student teachers expressed:}

I think written feedback will be more effective because you can look at your negative points when you want. I could think in negative points when I want.

Written feedback because this type of feedback will remain with students and students will return to it when they need it.

The written form is documentary and helpful for future use for both students and teachers. The documentary notes would serve very much when student come to office on later stage to inquire about their progress and it could be used for problematic areas such as the way they prepare their lesson plans.

I think that written feedback will be more effective because you can look at your negative points when you want. I could think in negative points when I want.

However, some of them argued than both of them are important: 
I think both are effective, but the written feedback allows us to read than the former, and oral feedback gives us a chance to discuss it with the mentor and ask him / her some questions based on the lesson.

I think both of them: in oral you have freedom to discuss it with your observer.

Both, but I think oral is more effective because written might be boring \& trainee teachers might not have the time to read it.

\section{In addition, student teachers expressed that oral is more effective}

In my point of view, I think oral feedback is more effective because you can get as much as feedback and you can discuss it with your mentor everything you did.

Oral because you can discuss it with your evaluator on the areas that were problematic during the lesson.

Oral because you can ask for clarification and you can interact and know more and reflect on your lesson.

In the light of the above responses, both types of feedback are effective according to the students' beliefs and most of them were appreciative. It could be argued that both types of feedback are important and they are complementary and they should be mutually inclusive not exclusive and they support each other. However, student teachers believed that written feedback is more effective to them than oral feedback during their school-based practicum.

\section{Conclusions, Pedagogical Implications and Recommendations}

Limitations of the study need to be acknowledged. The scope of the study covers only 46 of the student teachers out of 150 and 20 mentors out of 12 which might not be representative to the whole population and may impede generalizations. The findings of this study can be seen as illustrative rather than conclusive which cannot be generalized. This paper argues for how practicum feedback is perceived and what kind of feedback do student teachers receive in their practicum, and what type of practicum feedback is more effective, oral or written. The findings showed that the majority of the student teachers and their mentors perceive the practicum feedback positively, both oral and written feedback are important to them, a considerable number of student teachers are satisfied with their practicum feedback and the way it is given, and a great number of student teachers consider written feedback is more effective than oral feedback. This study has pedagogical implications for improving student teachers' pedagogical skills and knowledge which are both student teachers and their supervisors view both types of feedback as important, however, student teachers prefer written feedback as they can refer to it at any time. They both view the provision of feedback positively, and both positive and negative points should be highlighted in the feedback sessions. The findings might help mentors, and supervisors and decision makers in improving and promoting reflective school-based practicum feedback. Based on the findings, the study puts some recommendations that could help in improving what kind feedback given, how to give it, in what manner, etc.

School-based practicum should be given more attention, as all the students stressed that it is very important and contributes to their learning substantially. Further, school-based practicum practices should be aligned with the theoretical input that students receive in the college. Additionally, feedback should not be imposed on student teachers, but rather it should be dialogic between student teachers and their mentors. Feedback should be given instantly, as student teachers believe that instant feedback is more helpful for them than the delayed one. Furthermore, both written and oral feedback should be given to student teachers, written feedback should be over-emphasized and negative and positive points should be highlighted. Thus, the stakeholders concerned with school-based practicum should put into consideration these recommendations, which can help to improve the practice of feedback provision and school-based practicum practice in general.

\section{Acknowledgements}

We would like to express our genuine gratitude to all the teachers and students who took part in this study, without their participation the completion of the study would not have been possible. Also, we would like to thank Dr. Sufian Al Tayeb for his consultancy on statistical analysis and graphs presentations. Many thanks are also due to the journal editor and reviewers for their constructive feedback and comments on the draft.

\section{References}

Al Sohbani, Y. A. (2012). Prospective EFL teachers' perception of the teaching practice experience at AUST. Arab World English Journal, 3(4), 195-213. Retrieved from http://www.awej.org

Al-Mekhlafi, M. A. (2012). Self-perception and practices of a group of Omani cooperating teachers for supervising EFL student teachers' grammar teaching during practicum. Arab World English Journal, 3(4), 
160-178. Retrieved from http://www.awej.org

Borg, S. (Ed.). (2009). Researching English language teaching and teacher development in Oman. Ministry of Education. Sultanate of Oman. Retrieved from http://www.moe.gov.om/portal/sitebuilder/sites/eps/english/ips/.../2.aspx

Cameron-Jones, M., \& O'Hara, P. (1999). Student perception of the way that they are supervised during work experience: an instrument and some findings. Assessment \& Evaluation in Higher Education Journal, 24(1), 91-103. http://dx.doi.org/10.1080/0260293990240108

Copland, F. (2010). Causes of tension in post-observation feedback in pre-service teacher training: An alternative view. Teacher and Teacher Education Journal, 26, 466-472. http://dx.doi.org/10.1016/j.tate.2009.06.001

Copland, F. (2011). Negotiating face in feedback conferences: A linguistic ethnographic analysis. Journal of Pragmatics, 43, 3832-3843. http://dx.doi.org/10.1016/j.pragma.2011.09.014

Edwards, M. (1993). What is wrong with practicum? Some reflections. South Specific Journal of Teacher Education, 2(1), 33-43. http://dx.doi.org/10.1080/011213930210105

Ferrier-Kerr, J. (2009). Establishing professional relationship in practicum settings. Journal of Teaching and Teacher Education, 25, 790-797. http://dx.doi.org/10.1016/j.tate.2009.01.001

Hattie, J., \& Timperley, H. (2007). The power of feedback. Review of Educational Research, 77(1), 81-112. http://dx.doi.org/10.3102/003465430298487

Hussein, J. W. (2001). Impediments to educative practicum: The case of teacher preparation in Ethiopia. Research in Post-Compulsory Education Journal, 16(3), 333-355. http://dx.doi.org/10.1080/13596748.2011.602244

Moody, J. (2009). Key elements in a positive practicum: Insights from Australian post-primary pre-service teachers. Irish Educational Studies Journal, 28(8), 155-175. http://dx.doi.org/10.1080/03323310902884219

Mtika, P. (2011). Trainee teachers' experiences of teaching practicum: Issues, challenges, and new possibilities. Africa Education Review, 8(3), 551-567. http://dx.doi.org/10.1080/18146627.2011.618715

Schön, D. (1993). Educating the reflective practitioner: Towards a new design for teaching and learning in the professions. San Francisco: Jossey-Bass.

Selinger, H., \& Shohamy, E. (1989). Second language research methods. Cambridge: Cambridge University Press. http://dx.doi.org/10.1177/026765838900500201

Smith, K. (2010). Assessing the practicum in teacher education-Do we want candidates and mentors to agree? Studies in Educational Evaluation Journal, 36, 36-41. Retrieved from http://www.elsevier.com/stueduc

Tillema, et al. (2011). Dual roles-conflicting purposes: A comparative study on perceptions on assessment in mentoring relations during the practicum. European Journal of Teacher education, 34(2), 139-159. http://dx.doi.org/10.1080/02619768.2010.543672

White, S. (2007). Investigating effective feedback practices for pre-service teacher education students on practicum. Journal of Teacher Education, 18(4), 299-311. http://dx.doi.org/10.1080/10476210701687591

White, S. (2009). Articulation and re-articulation: Development of a model for providing quality feedback to pre-service teachers on practicum. Journal of Education for Teaching: International Research and Pedagogy, 35(2), 123-132. http://dx.doi.org/10.1080/02607470902770914

Wilson, G., \& I'Anson, J. (2006). Reframing the practicum: Constructing performative space in initial teacher education. Journal of Teaching and Teacher Education, 22, 353-361. http:// doi:10.1016/j.tate.2005.11.006

Yan, C., \& He, C. (2010). Transforming the existing model of teaching practicum: A study of Chinese EFL teachers' perceptions. Journal of Education for Teaching: International Research and Pedagogy, 36(1), 57-73. http://dx.doi.org/10.1080/02607470903462065 


\section{Appendix}

Table 1. What are the student teachers' perceptions of the practicum feedback they receive?

\begin{tabular}{|c|c|c|c|c|c|c|c|}
\hline \multirow{2}{*}{\multicolumn{2}{|c|}{$\begin{array}{l}\text { No } \quad \text { Statements } \\
\text { What are the student teachers' perceptions of the } \\
\text { practicum feedback they receive? }\end{array}$}} & \multicolumn{2}{|c|}{ Agree } & \multicolumn{2}{|c|}{$\begin{array}{l}\text { Neither Agree } \\
\text { Nor Disagree }\end{array}$} & \multicolumn{2}{|c|}{ Disagree } \\
\hline & & $\mathbf{F}$ & $\%$ & $\mathbf{F}$ & $\%$ & $\mathbf{F}$ & $\%$ \\
\hline 1 & $\begin{array}{l}\text { Peer feedback is useful and has helped me to } \\
\text { reflect. }\end{array}$ & 36 & $78 \%$ & 7 & $15 \%$ & 3 & $7 \%$ \\
\hline 2 & $\begin{array}{l}\text { The oral feedback is directive and effective than } \\
\text { the written feedback. }\end{array}$ & 24 & $54 \%$ & 15 & $32 \%$ & 7 & $15 \%$ \\
\hline 3 & I would to have both oral and written feedback. & 39 & $85 \%$ & 5 & $11 \%$ & 2 & $4 \%$ \\
\hline
\end{tabular}

Table 2. How satisfied are student teachers with their school-based practicum feedback?

\begin{tabular}{|c|c|c|c|c|c|c|c|c|c|}
\hline No & Statements & \multicolumn{2}{|c|}{$\begin{array}{l}\text { Extremely } \\
\text { Satisfied }\end{array}$} & \multicolumn{2}{|c|}{ Satisfied } & \multicolumn{2}{|c|}{ Dissatisfied } & \multicolumn{2}{|c|}{$\begin{array}{l}\text { Extremely } \\
\text { Dissatisfied }\end{array}$} \\
\hline \multicolumn{2}{|c|}{$\begin{array}{l}\text { Are student teachers more satisfied with the } \\
\text { school-based practicum feedback? }\end{array}$} & $\mathbf{F}$ & $\%$ & $\mathbf{F}$ & $\%$ & $\mathbf{F}$ & $\%$ & $\mathbf{F}$ & $\%$ \\
\hline 1 & Quality of your mentor's Feedback. & 7 & $15 \%$ & 28 & $61 \%$ & 6 & $13 \%$ & 0 & 0 \\
\hline 3 & Peer-mentoring and feedback. & 8 & $17 \%$ & 28 & $61 \%$ & 8 & $17 \%$ & 2 & $4 \%$ \\
\hline 4 & Written observation Feedback. & 9 & $19 \%$ & 27 & $59 \%$ & 9 & $20 \%$ & 1 & $2 \%$ \\
\hline 5 & Oral observation Feedback. & 16 & $35 \%$ & 24 & $52 \%$ & 6 & $13 \%$ & 0 & 0 \\
\hline 6 & $\begin{array}{l}\text { Your relationship with your mentor and } \\
\text { his / her feedback approach. }\end{array}$ & 14 & $30 \%$ & 28 & $61 \%$ & 4 & $9 \%$ & 0 & 0 \\
\hline 7 & The amount of the observation feedback. & 15 & $33 \%$ & 26 & $57 \%$ & 4 & $9 \%$ & 0 & 0 \\
\hline 8 & The place and time of receiving feedback. & 8 & $17 \%$ & 25 & $54 \%$ & 9 & $20 \%$ & 2 & $4 \%$ \\
\hline 9 & The quality of feedback. & 12 & $26 \%$ & 27 & $59 \%$ & 5 & $11 \%$ & 1 & $2 \%$ \\
\hline
\end{tabular}

Table 3. What are the mentors' perceptions about the practicum and its feedback?

\begin{tabular}{|c|c|c|c|c|c|c|c|}
\hline \multirow{2}{*}{\multicolumn{2}{|c|}{$\begin{array}{l}\text { No } \mid \text { Statements } \\
\text { What are the mentors perceptions of the } \\
\text { practicum and the feedback they give? }\end{array}$}} & \multicolumn{2}{|c|}{ Agree } & \multicolumn{2}{|c|}{$\begin{array}{l}\text { Neither Agree } \\
\text { Nor Disagree }\end{array}$} & \multicolumn{2}{|c|}{ Disagree } \\
\hline & & $\mathbf{F}$ & $\%$ & $\mathbf{F}$ & $\%$ & $\mathbf{F}$ & $\%$ \\
\hline 1 & Peer feedback is used in practicum. & 6 & $50 \%$ & 3 & $25 \%$ & 3 & $25 \%$ \\
\hline 2 & $\begin{array}{l}\text { Feedback on practicum should include } \\
\text { comments on planning, teaching strategies, } \\
\text { class management, personal attributes and } \\
\text { language proficiency. }\end{array}$ & 12 & $100 \%$ & 0 & 0 & 0 & 0 \\
\hline 3 & $\begin{array}{l}\text { Student teachers are provided with both oral } \\
\text { and written feedback. }\end{array}$ & 11 & $92 \%$ & 0 & 0 & 1 & $8 \%$ \\
\hline 4 & $\begin{array}{l}\text { The oral feedback is directive and more } \\
\text { effective for my students than written } \\
\text { feedback. }\end{array}$ & 6 & $50 \%$ & 4 & $33 \%$ & 2 & $17 \%$ \\
\hline 5 & $\begin{array}{l}\text { Feedback should include both positive and } \\
\text { negative comments on student teachers' } \\
\text { performance. }\end{array}$ & 12 & $100 \%$ & 0 & 0 & 0 & 0 \\
\hline
\end{tabular}


Table 4. What are the mentors' perceptions of the practicum and the feedback they give?

\begin{tabular}{|c|c|c|c|c|c|c|c|}
\hline \multirow{2}{*}{\multicolumn{2}{|c|}{$\begin{array}{l}\text { No } \text { Statements } \\
\text { What are the mentors' perceptions of the practicum and the } \\
\text { feedback they give? }\end{array}$}} & \multicolumn{2}{|c|}{ Agree } & \multicolumn{2}{|c|}{$\begin{array}{l}\text { Neither Agree } \\
\text { Nor Disagree }\end{array}$} & \multicolumn{2}{|c|}{ Disagree } \\
\hline & & \multirow{2}{*}{$\begin{array}{l}\mathbf{F} \\
11\end{array}$} & \multirow{2}{*}{$\begin{array}{l}\% \\
92 \%\end{array}$} & \multirow{2}{*}{$\begin{array}{c}\mathbf{F} \\
1\end{array}$} & \multirow{2}{*}{$\begin{array}{l}\% \\
8 \%\end{array}$} & \multirow{2}{*}{$\begin{array}{l}\mathbf{F} \\
0\end{array}$} & \multirow{2}{*}{$\begin{array}{l}\% \\
0\end{array}$} \\
\hline 6 & $\begin{array}{l}\text { Student teachers should receive detailed comments on their } \\
\text { performance. }\end{array}$ & & & & & & \\
\hline 7 & $\begin{array}{l}\text { Instant feedback is more effective and helpful for my } \\
\text { students than delayed feedback. }\end{array}$ & 11 & $92 \%$ & 0 & 0 & 1 & $8 \%$ \\
\hline 8 & $\begin{array}{l}\text { My student teachers can easily understand my feedback on } \\
\text { their performance. }\end{array}$ & 11 & $92 \%$ & 1 & $8 \%$ & 0 & 0 \\
\hline 9 & $\begin{array}{l}\text { My student teachers use my feedback in their practicum } \\
\text { regularly, }\end{array}$ & 9 & $75 \%$ & 1 & $8 \%$ & 1 & $8 \%$ \\
\hline 12 & $\begin{array}{l}\text { The current practice of providing feedback on practicum } \\
\text { needs to be improved. }\end{array}$ & 6 & $50 \%$ & 4 & $33 \%$ & 1 & $8 \%$ \\
\hline 10 & $\begin{array}{l}\text { Student teachers often reflect on the feedback they receive } \\
\text { on their performance. }\end{array}$ & 6 & $50 \%$ & 4 & $33 \%$ & 2 & $\begin{array}{l}17 \\
\%\end{array}$ \\
\hline 11 & $\begin{array}{l}\text { The feedback on practicum is consistent with what is } \\
\text { taught in the college-based practicum. }\end{array}$ & 2 & $17 \%$ & 8 & $67 \%$ & 1 & $8 \%$ \\
\hline
\end{tabular}

\section{Questions for focus group interview with supervisors}

1. What kind of feedback is given to student teachers on practicum?

(Prompts: Oral (face-to-face), written feedback,)

2. Which feedback do you think is more important \& useful to trainees, oral or written feedback or both?

3. What does feedback on practicum focus on?

(Prompts: Planning, teaching strategies, class management; language proficiency, personality attributes; positive or negative points or both)

4. How is feedback on practicum provided to trainees?

(Prompts: Supervisor - trainee; peer feedback; Supervisor with observed trainee and other trainees; discussion; points)

5. What do you think the impact of feedback on student teachers' teaching skills \& their future professional development?

6. What do you think are the challenges and problems encountered during school-based practicum?

7. What suggestions can you make to improve the practice of feedback provision on practicum?

(Prompts: How should feedback be given? Who should give feedback? When? Where? What kind of feedback should be given to student teachers?)

8. What types of feedback is more effective, oral or written? Why?

(Prompts: oral, written)

\section{Focus group interview notes in details}

Date: Monday 11 June 2012 Time: 11: 20 am Venue: Al Joda Hall

Present: Mark, Charles, Antony, Dr. Nagham, Moza, Mahmoud, Chris, Dr. Hamed \& Holi.

Discussion in Details:

Q1: Oral or written?

- CR: Oral feedback is better and it should be dialogic (what you write down is not always taken into account by students). 
- MR: Sometimes you do not have to write, therefore the oral is better (sometimes hand writing is 'horrendous' \& not clear enough, therefore, oral feedback works better with boys rather than girls.

- NG: the written form is documentary \& helpful for future use for both students \& teachers. The documentary notes would serve very much when students come to office on later stage to inquire about their progress \& it could be used for problematic areas such as the way they prepare their lesson plans.

- $\quad$ ANT: Written notes are very useful \& valuable for further feedback.

- NG: How can we achieve my objectives if there are not documented. Written feedback is highly important.

- $\quad$ MZ: We do need to train our students how to deal with feedback.

- ANT: Training on important issues we look at on observation needs to be provided. If there is not written feedback that means there are no records. If we ask teachers to document what they have observed this is going to more structured \& useful.

- $\quad$ NG: There should be a place in the lesson plan for students to reflect on. Observation form needs to be reconsidered because it has got overlapping points. I find it difficult to explain the form points to my students. It should be kept simple with 10-20 points.

- $\quad$ MR: students need to keep their lesson plans in a folder to be inspected.

- $\quad$ ANT: Students finish their practicum but they do not have any records. But oral feedback work well (it gives individual attention).

- $\quad$ ANT: Group discussion is needed \& students can learn from each other. There is a huge difference between boys \& girls in practicum.

- $\quad$ CH: In oral feedback students should record \& take notes to make use of it.

- ANT: (four hours practicum) is not enough to give a real discussion \& feedback. The value of feedback should be institutionalized. No attention is given to time needed for feedback. Both types of feedback are important. If you had more time to train your students, you would have helped them to make use of their feedback

There should be a book approach rather than the tick approach which is not useful in giving feedback.

- CR: Getting much feedback (too many points) was not accepted by students and they had a complaint about that $\&$ it had become a significant problem in the past. Therefore, focus should be kept on only on one aspect per visit (obvious problems). Giving them too many points may make them lose their confidence. Form needs to be changed to one can be commented on.

- ANT: Peer observations are very important \& students could learn from each other.

- CR: Students need to put in a meeting (to be briefed about what is required from them during their practicum).

- $\quad$ NG: Suggested socializing practicum.

- ANT: (Getting four trainees to observe an experienced teacher \& analyse a lesson) at the beginning of the semester is really useful \& they can learn how to reflect \& this going to be more structured \& institutionalized practices instead of an abrupt teaching by 'throwing them into the deep sea'.

- CR: Top management should be involved in practicum issues.

- MR: the observation form is 'rubbish'. The check list needs to be improved \& it could help everybody to pass. It should include some parts for creativity. Students sometimes complain about the contradictory feedback that they receive from two different supervisors.

- CR: It is difficult to change the form because it was prepared \& approved by the ministry $\&$ it took a long time to be finalized.

- ANT: (Group feedback) minimum 3 should be utilized \& this should include self-evaluation \& they need to teach their peers about their lessons. But if you are doing four observations it is difficult to give good group feedback or discussion. Group discussion is good for keeping them as a team). Teachings profession requires every trainee teacher to be a team player; therefore, group feedback is usually useful.

- $\quad$ CH: He would prefer one-to-one feedback.

- MH: Prefer group feedback. 


\section{Concluding remarks}

They all agree that both types of feedback are important \& they are complementary to each other. They are mutually inclusive not exclusive \& they complement each other. 